\title{
Determinan perempuan bekerja di Jawa Barat
}

\section{Determinats of female labor force in West Java}

\author{
Karina Damayanti \\ Sekolah Pascasarjana, Universitas Gadjah Mada
}

\begin{abstract}
This study aims to determine the characteristics of female labor force, women's main employment, and the individual and contextual factors that influence those two situations in West Java Province. The data sources used for this study are National Social-Economic Survey on March 2018 as well as publications on Gross Domestic Product (GDP) and Statistics of Education. This study applies three-levels binary logistics (individual, household, and city/regency) for data analysis. The independent variables that significantly affects women's employment status are age, education, marital status, household per capita expenditure, number of non-productive household members, household members, sex ratio, residence status, GDP per capita, agricultural contribution to GDP, and mean years schooling. However, access to information does not significantly influence the working status of women. This paper indicates that education is the primary determinant factor in regard to women's participation in labor force. Education is suggested to improve women's skills and knowledge that resulted in the advancement of the quality of female labors.
\end{abstract}

Keywords: female labor force, multilevel binary logistics, individual factors, contextual factors

\begin{abstract}
ABSTRAK
Penelitian ini bertujuan untuk mengetahui karakteristik perempuan bekerja, lapangan pekerjaan utama perempuan, serta faktor individual dan kontekstual yang memengaruhi kedua kondisi tersebut di Provinsi Jawa Barat. Sumber data yang digunakan adalah Sensus Sosial Ekonomi Nasional (Susenas) Maret 2018 dan publikasi Produk Domestik Regional Bruto (PDRB) dan Statistik Pendidikan. Kajian ini melakukan analisis dengan menggunakan metode multilevel logistik biner tiga level (individu, rumah tangga, dan kabupaten/kota). Variabel bebas yang berpengaruh secara signifikan terhadap status bekerja perempuan adalah umur, pendidikan, status kawin, pengeluaran per kapita rumah tangga, jumlah anggota rumah tangga nonproduktif, jumlah anggota rumah tangga, rasio jenis kelamin, status tempat tinggal, PDRB per kapita, kontribusi pertanian terhadap PDRB, dan rata-rata lama sekolah. Sementara itu, faktor akses informasi tidak berpengaruh signifikan terhadap partisipasi perempuan dalam pasar kerja. Kajian ini mengindikasikan bahwa pendidikan merupakan faktor penentu utama dalam status bekerja wanita. Pendidikan dapat meningkatkan kemampuan dan pengetahuan perempuan, yang pada akhirnya meningkatkan kualitas tenaga kerja perempuan.
\end{abstract}

Kata kunci: perempuan bekerja, multilevel logistik biner, faktor individual, faktor kontekstual

\section{PENDAHULUAN}

Jumlah penduduk perempuan hampir sama dengan jumlah penduduk laki-laki (BPS, 2018). Berdasarkan kondisi ini, perempuan seharusnya dapat memberikan kontribusi nyata dengan berpartisipasi aktif dalam perekonomian. Penduduk perempuan produktif yang tidak aktif secara ekonomi akan menjadi beban tanggungan bagi rumah tangganya, atau dalam lingkup yang lebih luas, dapat meningkatkan economic support ratio.
Perempuan memiliki peran dan kontribusi penting dalam ketenagakerjaan di Indonesia. Perempuan memiliki kontribusi sekitar $40 \%$ terhadap angkatan kerja di Indonesia. Perubahan Tingkat Partisipasi Angkatan Kerja (TPAK) merupakan salah satu indikator perubahan keterlibatan perempuan dalam pasar kerja. Sementara itu, masuknya perempuan dalam pasar kerja merupakan salah satu bentuk pemberdayaan 
perempuan (Hosney, 2016). Dengan kata lain, semakin besar keterlibatan perempuan dalam pasar kerja, perempuan juga semakin berdaya, bukan hanya dalam aspek ekonomi, tetapi juga dalam aspek sosial budaya dan politik. Isu pemberdayaan perempuan secara khusus dalam Sustainable Development Goals (SDGs) disebutkan dalam tujuan 5 (mencapai kesetaraan gender dan memberdayakan semua perempuan dan anak perempuan) (UNDP, 2016).

TPAK perempuan berada di bawah TPAK laki-laki, hanya setengah dari perempuan berusia kerja yang bekerja. Kondisi ini dalam beberapa publikasi disebutkan bahwa, TPAK perempuan Indonesia mengalami stagnansi (Kementerian Pemberdayaan Perempuan dan Perlindungan Anak, 2016; Tanaka \& Muzones, 2016). Apabila TPAK perempuan Indonesia dibandingkan dengan beberapa negara tetangga di Asia, Indonesia menempati posisi tengah, sejajar dengan capaian TPAK negara Filipina, tetapi masih lebih rendah dibanding Kamboja dan Vietnam (ILO, 2017).

Pentingnya peran perempuan dalam ekonomi dapat dilihat dari dua aspek. Di satu sisi, partisipasi perempuan dalam pasar kerja merupakan motor penggerak dan juga sekaligus sebagai hasil dari pertumbuhan dan pembangunan ekonomi (Verick, 2014). Pembangunan ekonomi dapat memperbaiki kondisi perempuan dan menurunkan ketimpangan antara laki-laki dan perempuan. Di sisi lain, keterlibatan perempuan dalam ekonomi merupakan salah satu kunci dari pertumbuhan ekonomi. Ketika lebih banyak perempuan yang bekerja dan berdaya, akan menimbulkan multiplier effect dalam hal pertumbuhan ekonomi dan pembangunan di segala bidang (Verick, 2014; UNDP, 2016).

Pentingnya peran perempuan dalam pembangunan ekonomi dapat dilihat dari besarnya kontribusi mereka terhadap Produk Domestik Bruto (PDB). Sebagai contoh, penelitian yang dilakukan oleh Ehsan (2015) di Pakistan, menunjukkan bahwa rendahnya partisipasi perempuan dalam pasar kerja menurunkan capaian PDB hingga 33-53\%. Angka ini mempertegas kontribusi penting perempuan dalam pembangunan ekonomi suatu wilayah. Partisipasi perempuan sama dengan laki-laki dapat meningkatkan ca- paian PDB tahunan sebesar $26 \%$ pada tahun 2025. Aspek lain yang penting adalah kenaikan partisipasi perempuan dalam angkatan kerja akan mengakibatkan penurunan kesenjangan ekonomi antara perempuan dan laki-laki. Hal inilah yang menjadi motor penggerak untuk mendorong pertumbuhan ekonomi yang lebih cepat.

Jawa Barat mengalami capaian indikator ketenagakerjaan yang kurang baik jika dibandingkan dengan provinsi lain di Indonesia. TPAK dan Employment to Population Ratio (EPR) perempuan Jawa Barat terendah nasional $(42,37 \%$ dan $38,68 \%$ ) (BPS, 2018). Pengangguran perempuan menempati posisi kedua teratas di Indonesia $(8,70 \%)$ (BPS, 2018). Kondisi ini dihadapkan dengan fakta bahwa Jawa Barat adalah provinsi dengan jumlah penduduk terbesar pada tahun 2018, yaitu 48,48 juta jiwa, angka ini menyumbang $18 \%$ jumlah penduduk Indonesia.

Berbagai penelitian tentang aktivitas ekonomi perempuan dilakukan dengan analisis pada level individu. Artinya, faktor yang menjelaskan mengapa perempuan bekerja dianalisis berdasarkan kondisi individu perempuan. Ada faktor penting yang jarang digunakan sebagai prediktor terhadap keputusan perempuan untuk bekerja, yaitu faktor daerah atau kontekstual. Pentingnya faktor ini didasarkan pada asumsi pokok bahwa kondisi daerah atau wilayah akan memengaruhi keputusan perempuan untuk bekerja atau tidak. Hal tersebut terkait dengan kondisi ekonomi dan kesempatan kerja yang tersedia di wilayah tersebut. Hasil penelitian Verick (2014) menunjukkan bahwa faktor kontekstual dan struktur di tempat perempuan tersebut tinggal memengaruhi partisipasi perempuan dalam pasar kerja. Oleh karena itu, penting untuk menganalisis secara bersama-sama faktor individual dan faktor kontekstual di tempat perempuan tersebut tinggal.

Pertanyaan penelitian ini adalah sebagai berikut: (i) Bagaimana karakteristik sosial, ekonomi dan demografi perempuan (15-64 tahun) yang bekerja? dan (ii) Bagaimana pengaruh faktor kontekstual dan individual terhadap keputusan perempuan untuk bekerja? Berdasarkan pertanyaan penelitian tersebut, tujuan penelitian ini adalah untuk menganalisis pengaruh faktor kontekstual dan individual terhadap keputusan perempuan untuk bekerja. 


\section{TINJAUAN PUSTAKA}

Fenomena $U$-shaped adalah hubungan tingkat partisipasi angkatan kerja perempuan dengan kondisi ekonomi suatu negara. Fenomena U-shaped adalah fenomena meningkatnya partisipasi pekerja perempuan dengan pendapatan nasional per kapita yang terjadi di negara-negara berpenghasilan rendah dan negara yang sangat maju, tetapi relatif rendah pada negara berpenghasilan menengah (Goldin, 1995; Gaddis \& Klasen, 2014). Indonesia adalah salah satu negara yang memiliki fenomena $U$-shaped antara partisipasi perempuan dalam pasar kerja dan kondisi ekonomi yang diukur dengan capaian PDB per kapita (Verick, 2014).

Becker (1992) dalam teori alokasi waktu menyatakan bahwa partisipasi pekerja di pasar kerja merupakan pilihan antara kesediaan tenaga kerja secara individu untuk bekerja (work for paid) atau memilih tidak bekerja (leisure). Konsekuensinya, jika seseorang memilih salah satu pilihan berarti waktu untuk pilihan yang lain akan semakin berkurang. Ehrenberg dan Smith (2012) dalam teori produksi rumah tangga memberikan pilihan antara waktu yang dialokasikan untuk santai (leisure), bekerja di rumah (unpaid work) atau bekerja untuk mendapatkan upah di pasar kerja (paid work). Keputusan yang diambil untuk setiap rumah tangga dalam memutuskan seorang perempuan bekerja atau tidak dapat terjadi dalam tiga cara, yaitu (i) keputusan diambil kepala keluarga; (ii) keputusan merupakan hasil dari kesepakatan bersama, dan (iii) setiap pasangan bergerak secara independen untuk memaksimalkan kompetensi tiap individu. Lebih lanjut, $h u$ man capital theory (Schultz, 1961; Becker, 1992) menekankan pentingnya pendidikan dan pelatihan sebagai kunci untuk berpartisipasi dalam pasar tenaga kerja. Pendidikan dan pelatihan dianggap sebagai investasi yang meningkatkan produktivitas individu dan meningkatkan kemungkinan individu untuk mendapatkan status pekerjaan dan penghasilan yang lebih tinggi.

Terdapat dua alasan yang mendasari seorang perempuan untuk bekerja. Pertama, perempuan harus bekerja adalah mereka yang secara ekonomi tidak beruntung. Kedua, perempuan me- milih bekerja adalah mereka yang dapat membuat pilihan-pilihan dalam hidupnya apakah memilih bekerja atau tidak. Kondisi ekonomi perempuan dalam kelompok kedua lebih baik daripada perempuan pada kelompok pertama.

Sobol (dalam Widarti, 1998) menunjukkan bahwa terdapat tiga kondisi perempuan memasuki pasar kerja. Pertama adalah kondisi yang memungkinkan. Perempuan yang belum kawin akan lebih mungkin untuk bekerja dibanding dengan perempuan yang sudah kawin. Kedua adalah kondisi yang memfasilitasi. Salah satu kondisi yang memudahkan adalah dampak kuat pendidikan terhadap perempuan dan isu kesetaraan gender. Ketiga adalah kondisi yang mencetuskan, yaitu kondisi ketidakpuasan terhadap pendapatan rumah tangga dan ketidakpuasan personal sehingga perempuan memutuskan untuk bekerja.

Menurut Spierings dkk. (2010), faktor individual dan kontekstual yang memengaruhi perempuan untuk bekerja dibedakan menjadi tiga. Faktor yang pertama adalah needs (kebutuhan), yaitu syarat yang harus dipenuhi pada tingkat rumah tangga baik yang berupa kebutuhan yang sifatnya materi maupun pengasuhan. Faktor kedua yaitu opportunities (kesempatan), dicirikan dengan tersedianya pekerjaan yang sesuai dan tersedianya akses terhadap pekerjaan, kesempatan merupakan turunan dari modal manusia, jejaring sosial, dan akses informasi. Faktor ketiga adalah values (norma) norma yang melekat pada perempuan, yaitu pada pekerjaan rumah tangga dan pengasuhan. Kondisi ini membatasi perempuan untuk berperan secara aktif dalam pasar kerja.

\section{DATA DAN METODE PENELITIAN}

Data yang digunakan dalam penelitian ini adalah data sekunder hasil survei Sosial Ekonomi Nasional (Susenas) Maret tahun 2018, publikasi Tinjauan Regional Berdasarkan PDRB Kabupaten/Kota Tahun 2013-2017, dan publikasi IPM Nasional Tahun 2017. Unit analisis dalam penelitian ini adalah perempuan usia produktif berumur 15-64 tahun yang masuk dalam kategori angkatan kerja, yaitu mereka yang sedang bekerja, mempersiapkan atau mencari pekerjaan.

Variabel tidak bebas dalam penelitian ini adalah status bekerja perempuan dengan respon 
biner apakah bekerja (1) atau tidak (0). Faktor kontekstual dan individual yang memengaruhi variabel tidak bebas dibagi menjadi tiga level hirarki, yaitu level individu (level 1), level rumah tangga (level 2), dan level kabupaten/ kota (level 3). Faktor individual merupakan variabel bebas yaitu pada level individu. Faktor kontekstual merupakan variabel bebas yang berada pada level rumah tangga dan kabupaten/kota. Variabel bebas pada level individu yang digunakan dalam penelitian ini adalah umur, status kawin, tingkat pendidikan, dan akses informasi. Variabel bebas pada level rumah tangga adalah jumlah anggota rumah tangga, pengeluaran per kapita rumah tangga, jumlah anggota rumah tangga non produktif, rasio jenis kelamin, dan status tempat tinggal. Sementara itu, variabel bebas pada level kabupaten/kota adalah PDRB per kapita, kontribusi sektor pertanian dalam PDRB, dan rata-rata lama sekolah. Terkait dengan keberadaan struktur hirarki yang terdapat pada data yang digunakan, penelitian ini menggunakan metode multilevel logistik dengan respon biner. Metode ini meminimalisasi terjadinya kesalahan kontekstual yang disebabkan karena adanya error yang berkorelasi dalam setiap individu yang berada pada kelompok yang sama yang menyebabkan bias dalam mengestimasi parameter (Hox, 2010; Ghozali, 2016).

\section{HASIL DAN PEMBAHASAN}

Karakteristik perempuan usia produktif yang berstatus sebagai pekerja mayoritas berada pada rentang umur 30-49 tahun, berpendidikan rendah ( $\leq$ sekolah dasar), berstatus kawin atau pernah kawin, memiliki akses terhadap informasi, sebagian besar tinggal pada keluarga dengan pengeluaran per kapita lebih dari 1.834 .557 rupiah (kuintil 5) per bulan, tinggal pada rumah tangga dengan anggota rumah tangga $\leq 4$ dan jumlah anggota rumah tangga non produktif $\leq 2$, dengan komposisi jenis kelamin perempuan yang lebih rendah atau sama dengan laki-laki, serta tinggal di wilayah perkotaan (Tabel 1).

Tabel 2 menyajikan hasil dari analisis multilevel, model 0 merupakan model yang hanya
Tabel 1. Karakteristik perempuan usia produktif (1564 tahun) berstatus bekerja berdasarkan variabel level individu dan rumah tangga di Provinsi Jawa Barat

\begin{tabular}{|c|c|c|}
\hline Variabel & Jumlah & $\%$ \\
\hline \multicolumn{3}{|l|}{ Tingkat pendidikan } \\
\hline Pendidikan rendah $(\leq \mathrm{SD})$ & 4.094 & 38,3 \\
\hline $\begin{array}{l}\text { Pendidikan menengah } \\
\text { (SMP-SMA) }\end{array}$ & 4.904 & 45,8 \\
\hline Pendidikan tinggi (PT) & 1.700 & 15,9 \\
\hline \multicolumn{3}{|l|}{ Umur } \\
\hline $15-29$ & 2.923 & 27,3 \\
\hline $30-49$ & 5.569 & 52,1 \\
\hline $50-64$ & 2.206 & 20,6 \\
\hline \multicolumn{3}{|l|}{ Akses informasi } \\
\hline Tidak ada & 1.600 & 15,0 \\
\hline Ada & 9.098 & 85,0 \\
\hline \multicolumn{3}{|l|}{ Status kawin } \\
\hline Belum kawin & 1.774 & 16,6 \\
\hline Kawin & 7.478 & 69,9 \\
\hline Cerai hidup & 657 & 6,1 \\
\hline Cerai mati & 789 & 7,4 \\
\hline \multicolumn{3}{|l|}{ Pengeluaran per kapita per bulan } \\
\hline Kuintil $1(<555.106)$ & 1.396 & 13,0 \\
\hline Kuintil $2(555.106-793.586)$ & 1.830 & 17,1 \\
\hline Kuintil $3(793.586-1.196 .959)$ & 2.051 & 19,2 \\
\hline Kuintil 4 (793.586 - 1.904.162) & 2.346 & 21,9 \\
\hline Kuintil $5(>1.904 .162)$ & 3.075 & 28,7 \\
\hline \multicolumn{3}{|l|}{ Rasio jenis kelamin } \\
\hline Perempuan $\leq$ laki-laki & 6.447 & 60,3 \\
\hline Perempuan > laki-laki & 4.251 & 39,7 \\
\hline \multicolumn{3}{|c|}{ Jumlah anggota rumah tangga (ART) } \\
\hline Jumlah ART $\leq 4$ & 7.444 & 69,6 \\
\hline Jumlah ART $>4$ & 3.254 & 30,4 \\
\hline \multicolumn{3}{|l|}{ Jumlah ART nonproduktif } \\
\hline$\leq 2$ & 7.468 & 69,8 \\
\hline$>2$ & 3.230 & 30,2 \\
\hline \multicolumn{3}{|l|}{ Status tempat tinggal } \\
\hline Perkotaan & 8.000 & 74,8 \\
\hline Perdesaan & 2.698 & 25,2 \\
\hline n level 1 (individu) & 1.4531 & \\
\hline n level 2 (rumah tangga) & 1.2567 & \\
\hline n level 3 (kabupaten/kota) & 27 & \\
\hline
\end{tabular}

Sumber: Olah data Susenas Maret 2018 Jawa Barat

terdiri dari intercept, model 1 terdiri atas variabel bebas pada level individu, model 2 terdiri atas variabel bebas pada model 1 dan rumah tangga, model 3 adalah model yang terdiri atas semua variabel bebas pada semua level, dan model 4 adalah variabel bebas pada model 3 ditambah variabel interaksi. 
Tabel 2. Model analisis multilevel perempuan bekerja di Jawa Barat

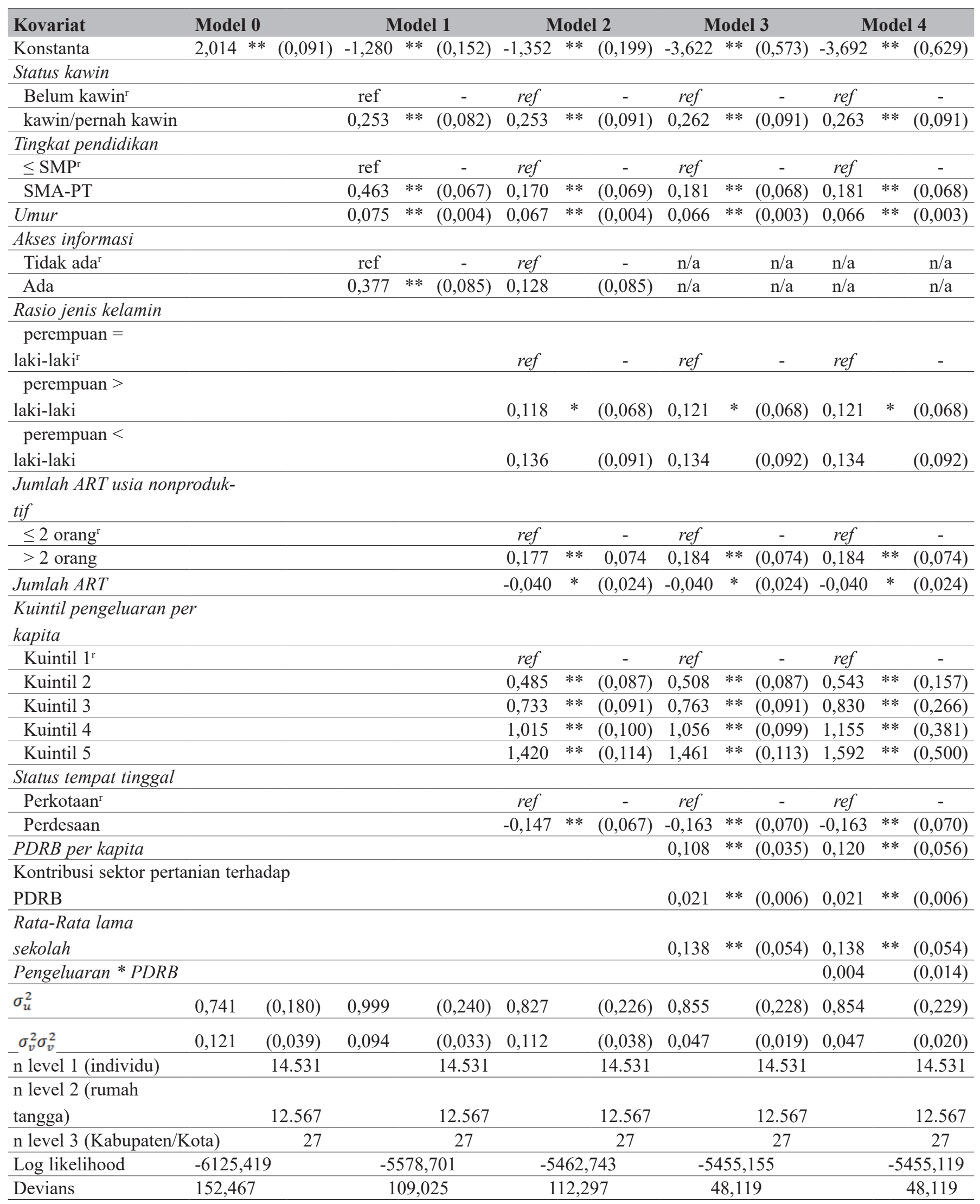

Catatan: $r$ kategori acuan; ** Signifikansi 5\%; * Signifikansi 10\%; n/a tidak diolah; (.) standar eror

Sumber: Olah data Susenas Maret 2018 Jawa Barat 


\section{Model 0}

Model null pada penelitian ini menghasilkan nilai konstanta yang signifikan pada level signifikansi 5\%. Nilai deviasi pada level ini paling besar dibanding nilai deviasi pada model lain. Semakin kecil nilai deviasi maka model semakin baik dalam menggambarkan data.

\section{Model 1}

Semua variabel pada level individu bekerja sesuai dengan teori. Semua variabel signifikan berpengaruh terhadap status bekerja perempuan. Status perempuan yang kawin atau pernah kawin, tingkat pendidikan yang semakin tinggi, semakin tua umur, dan adanya akses informasi berpengaruh positif dan signifikan terhadap status bekerja perempuan.

\section{Model 2}

Sebanyak delapan dari variabel bebas pada level individu dan rumah tangga berpengaruh signifikan terhadap status bekerja perempuan. Akses informasi yang signifikan memengaruhi status bekerja perempuan pada level individu, namun setelah variabel level rumah tangga dimasukkan memberikan hasil yang tidak signifikan. Rumah tangga dengan komposisi jumlah perempuan usia produktif yang lebih banyak, jumlah anggota rumah tangga usia nonproduktif dalam rumah tangga yang lebih dari dua, dan tingkat pengeluaran lebih besar memiliki pengaruh positif dan signifikan terhadap status bekerja perempuan. Jumlah anggota rumah tangga dan tinggal di wilayah perdesaan berpengaruh negatif dan signifikan terhadap status bekerja perempuan.

\section{Model 3}

Pada Model 3, variabel akses informasi dikeluarkan dari model karena tidak signifikan pada Model 2. Sebanyak 12 variabel bebas pada level individu, rumah tangga, dan kabupaten/kota berpengaruh signifikan terhadap status bekerja perempuan. Pertumbuhan PDRB per kapita, kontribusi sektor pertanian terhadap PDRB, dan rata-rata lama sekolah berpengaruh positif dan signifikan terhadap status bekerja perempuan. Artinya, semakin tinggi pertumbuhan PDRB per kapita suatu wilayah, semakin tinggi kontribusi sektor pertanian terhadap PDRB. Selanjutnya, semakin tinggi capaian rata-rata lama sekolah suatu daerah maka kesempatan bekerja perempuan akan semakin tinggi.

\section{Model 4}

Model ini adalah Model 3 yang ditambahkan variabel interaksi antara pengeluaran per kapita rumah tangga dengan pertumbuhan PDRB. Hasil pengolahan menunjukkan bahwa interaksi variabel tidak berpengaruh signifikan terhadap status bekerja perempuan. Nilai deviasi pada Model 4 sama dengan deviasi pada Model 3, sehingga model yang paling baik menggambarkan status bekerja perempuan adalah Model 3 tanpa variabel interaksi.

\section{Peluang Perempuan Bekerja}

Tabel 3 menyajikan hasil analisis model multilevel logistik biner yang memberikan estimasi peluang perempuan untuk berpartisipasi dalam pasar kerja.

\section{Umur}

Umur dianggap sebagai salah satu pendekatan tingkat kematangan dan pengalaman seseorang. Ketika umur seorang perempuan sudah memasuki usia kerja maka mereka memiliki keinginan untuk bekerja. Umur berpengaruh positif dan signifikan terhadap status bekerja perempuan. Kecenderungan perempuan untuk bekerja akan semakin tinggi 1,07 kali seiring dengan bertambahnya umur. Semakin tua umur seorang perempuan sampai dengan 64 tahun, peluang bekerja perempuan tersebut akan semakin tinggi. Hasil ini mengkonfirmasi penelitian sebelumnya yang dilakukan oleh Cipollone dkk. (2012), Majumder (2012); Mehrotra dan Parida (2017), dan Octaviana (2017) bahwa faktor umur secara signifikan memengaruhi partisipasi perempuan dalam angkatan kerja.

\section{Pendidikan}

Pendidikan adalah salah satu determinan yang paling kuat memengaruhi partisipasi perempuan di pasar kerja, baik di negara maju maupun negara berkembang (Verick, 2014). Pendidikan berpengaruh positif dan signifikan terhadap perempuan untuk bekerja. Kecenderungan perempuan 
Tabel 3. Estimasi parameter $(\beta)$ dan odds ratio model multilevel logistik biner status bekerja perempuan di Provinsi Jawa Barat

\begin{tabular}{|c|c|c|c|}
\hline Kovariat & Estimasi & & $\begin{array}{l}\text { Odds } \\
\text { Ratio }\end{array}$ \\
\hline (1) & (2) & & (3) \\
\hline Konstanta & $-3,622$ & $* *$ & \\
\hline \multicolumn{4}{|l|}{ Status kawin } \\
\hline Belum kawin ${ }^{\mathrm{r}}$ & 0,000 & & 1,00 \\
\hline Kawin/pernah kawin & 0,262 & $* *$ & 1,30 \\
\hline \multicolumn{4}{|l|}{ Tingkat pendidikan } \\
\hline$\leq \mathrm{SMP}^{\mathrm{r}}$ & 0,000 & & 1,00 \\
\hline SMA-PT & 0,181 & $* *$ & 1,20 \\
\hline Umur & 0,066 & $* *$ & 1,07 \\
\hline \multicolumn{4}{|l|}{ Akses informasi } \\
\hline Tidak ada ${ }^{\mathrm{r}}$ & $\mathrm{n} / \mathrm{a}$ & & $\mathrm{n} / \mathrm{a}$ \\
\hline Ada & $\mathrm{n} / \mathrm{a}$ & & $\mathrm{n} / \mathrm{a}$ \\
\hline \multicolumn{4}{|l|}{ Rasio jenis kelamin } \\
\hline Perempuan = laki-laki ${ }^{\mathrm{r}}$ & 0,000 & & 1,00 \\
\hline Perempuan > laki-laki & 0,121 & $*$ & 1,13 \\
\hline Perempuan < laki-laki & 0,134 & & 1,14 \\
\hline \multicolumn{4}{|l|}{$\begin{array}{l}\text { Jumlah ART usia non- } \\
\text { produktif }\end{array}$} \\
\hline$\leq 2$ orang $^{\mathrm{r}}$ & 0,000 & & 1,00 \\
\hline$>2$ orang & 0,184 & $* *$ & 1,20 \\
\hline Jumlah ART & $-0,040$ & $*$ & 0,96 \\
\hline \multicolumn{4}{|l|}{ Kuintil pengeluaran per } \\
\hline \multicolumn{4}{|l|}{ kapita } \\
\hline $\begin{array}{l}\text { Kuintil 1 } 1^{\mathrm{r}}(<\mathrm{Rp533.653)} \\
\text { Kuintil } 2 \text { (Rp533.653 - }\end{array}$ & 0,000 & & 1,00 \\
\hline $\begin{array}{l}\text { Rp757.595) } \\
\text { Kuintil } 3 \text { (Rp757.595 - }\end{array}$ & 0,508 & $* *$ & 1,66 \\
\hline $\begin{array}{l}\text { Rp1.134.098) } \\
\text { Kuintil } 4 \text { (Rp1.134.098 - }\end{array}$ & 0,763 & $* *$ & 2,14 \\
\hline Rp1.834.557) & 1,056 & $* *$ & 2,87 \\
\hline Kuintil 5 ( > Rp1.834.557) & 1,461 & $* *$ & 4,31 \\
\hline \multicolumn{4}{|l|}{ Status tempat tinggal } \\
\hline Perkotaan $^{\mathrm{r}}$ & 0,000 & & 1,00 \\
\hline Perdesaan & $-0,163$ & $* *$ & 0,85 \\
\hline PDRB per kapita & 0,108 & $* *$ & 1,11 \\
\hline \multicolumn{4}{|l|}{ Kontribusi sektor pertanian } \\
\hline terhadap PDRB & 0,021 & $* *$ & 1,02 \\
\hline Rata-rata lama sekolah & 0,138 & $* *$ & 1,15 \\
\hline$\sigma_{u}^{2}$ & 0,855 & & \\
\hline$\sigma_{v}^{2} \sigma_{v}^{2}$ & 0,047 & & 0,019 \\
\hline n level 1 (individu) & 14.531 & & \\
\hline n level 2 (rumah tangga) & 12.567 & & \\
\hline n level 3 (Kabupaten/Kota) & 27 & & \\
\hline
\end{tabular}

Catatan: r kategori acuan; ** Signifikansi 5\%; * Signifikansi 10\%; $\mathrm{n} / \mathrm{a}$ tidak diolah

Sumber: Susenas Maret 2018 Jawa Barat, diolah berpendidikan tinggi untuk bekerja lebih tinggi dibanding perempuan yang berpendidikan rendah. Peluang bekerja pada perempuan dengan pendidikan tinggi 1,2 kali lebih tinggi dibanding perempuan dengan pendidikan rendah (Tabel 3). Hasil ini sesuai dengan penelitian sebelumnya (Asiati, 2002; Cipollone \& D'Ippoliti, 2011; Hosney, 2016; Majumder, 2012; Mehrotra \& Parida, 2017; Octaviana, 2017; Schaner \& Das, 2016; Setyawati, 2010; Shi, 2015; Spierings dkk., 2010; Widarti, 1998) bahwa pendidikan penting bagi perempuan terutama dalam menentukan status bekerja perempuan. Investasi bidang pendidikan menentukan partisipasi perempuan di pasar kerja. Perempuan yang memiliki pendidikan yang lebih tinggi cenderung untuk masuk ke pasar kerja. Jika dilihat dari sisi penawaran, pendidikan memiliki dampak penting pada keputusan individu untuk berpartisipasi dalam angkatan kerja. Hal ini dikarenakan tingkat pendidikan menentukan pengetahuan dan kecakapan seseorang.

\section{Status kawin}

Status perempuan yang kawin atau pernah kawin berpengaruh positif dan signifikan terhadap status bekerja. Kecenderungan perempuan berstatus kawin atau pernah kawin untuk bekerja lebih tinggi 1,3 kali dibanding perempuan belum kawin. Hasil ini justru memberikan kesimpulan yang berbeda dari penelitian sebelumnya di India yang dilakukan oleh Majumder (2012) dan Mehrotra dan Parida (2017). Pada penelitian tersebut dinyatakan bahwa perempuan dengan status belum kawin cenderung lebih tinggi dibanding mereka yang berstatus kawin. Perbedaan budaya dan lokasi diduga menyebabkan perbedaan hasil penelitian yang dilakukan di India dan Indonesia ini. Penelitian lain yang dilakukan oleh Kusumaningrum (2013) di Sulawesi Tengah mendukung kajian ini. Peluang perempuan menjadi angkatan kerja semakin besar ketika perempuan tersebut berstatus kawin. Kondisi ini mungkin terjadi mengingat perempuan yang sudah berstatus kawin atau pernah kawin memiliki tingkat kebutuhan ekonomi rumah tangga yang lebih tinggi dibanding perempuan yang belum kawin. Alasan inilah yang mendorong perempuan berstatus kawin atau pernah kawin untuk bekerja. 


\section{Akses informasi}

Variabel akses informasi bekerja dengan baik dan signifikan memengaruhi status bekerja perempuan pada level individu, tetapi tidak bekerja dengan baik pada level rumah tangga dan kabupaten/ kota. Artinya, variabel ini berpengaruh ketika variabel pada level individu bekerja sendiri tanpa ada variabel lain pada level rumah tangga dan kabupaten/kota. Pada model akhir akses informasi tidak signifikan memengaruhi status bekerja perempuan. Hasil penelitian ini tidak sejalan dengan penelitian sebelumnya oleh Suhaida dkk. (2013) dan Nikulin (2017) yang menunjukkan adanya hubungan positif antara akses informasi dan komunikasi terhadap partisipasi perempuan di pasar kerja di negara berkembang. Keberadaan akses informasi membuka peluang bekerja pada perempuan. Dalam hal ini, bekerja adalah kegiatan melakukan pekerjaan dengan maksud memperoleh atau membantu memperoleh penghasilan atau keuntungan paling sedikit selama satu jam dalam seminggu terakhir (BPS, 2017). Hal ini memperbesar kemungkinan seseorang bekerja sebagai pekerja keluarga atau bekerja pada sektor pertanian informal, sehingga akses informasi dalam hal mendapatkan pekerjaan menjadi tidak terlalu penting.

\section{Jumlah anggota rumah tangga}

Jumlah anggota rumah tangga merepresentasikan beban ekonomi yang harus ditanggung setiap rumah tangga. Jumlah anggota rumah tangga berpengaruh negatif dan signifikan terhadap status bekerja perempuan. Kecenderungan perempuan untuk bekerja akan semakin rendah 0,96 kali seiring dengan bertambahnya jumlah anggota rumah tangga. Hasil penelitian ini tidak sejalan dengan penelitian sebelumnya yang dilakukan oleh Setyawati (2010) bahwa jumlah anggota rumah tangga berpengaruh positif dan signifikan terhadap peluang perempuan untuk bekerja. Semakin besar jumlah anggota rumah tangga berarti beban tanggungan rumah tangga semakin tinggi. Kondisi inilah yang meningkatkan peluang perempuan untuk bekerja. Peran perempuan di sini untuk menambah penghasilan rumah tangga dalam memenuhi kebutuhan hidup sehari-hari karena bertambahnya anggota rumah tangga.
Kondisi di Jawa Barat menunjukkan hal yang berlawanan dengan hasil penelitian sebelumnya, hal ini disebabkan karena masih adanya norma tradisional yang dianut pada rumah tangga di Jawa Barat. Posisi laki-laki dalam kegiatan ekonomi rumah tangga dianggap sebagai pencari nafkah yang utama (Spierings dkk., 2010; Ehsan, 2015). Sementara itu, perempuan adalah penanggung jawab utama urusan rumah tangga (Ehsan, 2015) dan pengasuhan anak, utamanya di negara berkembang (Tanaka \& Muzones, 2016). Posisi perempuan yang dianggap sebagai penanggung jawab urusan rumah tangga menyebabkan ketika jumlah anggota rumah tangga semakin banyak maka mereka cenderung di rumah untuk menyelesaikan berbagai urusan domestik. Hasil penelitian ini sejalan dengan hasil penelitian yang dilakukan oleh Groesbeck dan Israelsen (1994) dan Cools dkk. (2017) bahwa ukuran jumlah anggota rumah tangga berpengaruh negatif dan signifikan terhadap partisipasi bekerja perempuan. Hasil ini mengonfimasi bahwa norma tradisional peran gender dalam rumah tangga masih ada dalam hubungannya dengan pasar kerja.

\section{Pengeluaran per kapita rumah tangga}

Pengeluaran per kapita mencerminkan status ekonomi rumah tangga. Variabel pengeluaran per kapita rumah tangga berpengaruh positif dan signifikan terhadap status bekerja. Pengeluaran per kapita rumah tangga berpengaruh positif dan signifikan terhadap status perempuan bekerja. Semakin besar pengeluaran per kapita rumah tangga ( $\geq 533.653$ rupiah per kapita per bulan) maka peluang perempuan bekerja semakin besar, yaitu 1,66-4,31 kali lebih tinggi dibanding perempuan yang berada pada kuintil pengeluaran satu $(<$ 533.653 rupiah per kapita per bulan). Hasil ini sesuai dengan penelitian sebelumnya (Widarti, 1998; Kusumaningrum, 2013; Octaviana, 2017) yang menyatakan bahwa pengeluaran per kapita rumah tangga berpengaruh positif dan signifikan terhadap status bekerja perempuan. Semakin tinggi tingkat pengeluaran per kapita rumah tangga, maka peluang perempuan untuk bekerja akan semakin tinggi. Masuknya perempuan ke ranah bekerja diharapkan dapat meningkatkan pendapatan dan membantu memenuhi kebutuhan rumah tangga. 


\section{Rasio jenis kelamin rumah tangga}

Rasio jenis kelamin rumah tangga merupakan perbandingan antara jumlah anggota rumah tangga usia produktif (15-64 tahun) laki-laki dan perempuan. Pada variabel ini hanya kategori anggota rumah tangga perempuan lebih besar daripada laki-laki yang berpengaruh positif dan signifikan memengaruhi status bekerja perempuan. Peluang bekerja pada perempuan yang tinggal pada rumah tangga yang jumlah anggota rumah tangga perempuannya lebih besar daripada laki-laki 1,13 kali lebih tinggi dibanding perempuan yang tinggal pada rumah tangga yang jumlah anggota rumah tangga perempuannya sama dengan laki-laki.

Hasil ini sesuai dengan penelitian sebelumnya yang dilakukan oleh Majumder (2012) yang mengemukakan bahwa jumlah anggota rumah tangga perempuan yang lebih banyak dalam rumah tangga secara signifikan meningkatkan peluang perempuan untuk berpartisipasi di pasar kerja. Hal ini didasari karena tidak cukupnya pendapatan laki-laki dalam rumah tangga sehingga untuk memenuhi kebutuhan ekonomi perempuan harus berpartisipasi ke pasar kerja.

\section{Jumlah ART usia nonproduktif}

Jumlah anggota rumah tangga usia nonproduktif mencerminkan beban ekonomi yang harus ditanggung oleh anggota rumah tangga usia produktif. Jumlah anggota rumah tangga nonproduktif berpengaruh positif dan signifikan terhadap status bekerja perempuan. Peluang bekerja pada perempuan dengan jumlah anggota rumah tangga nonproduktif lebih dari dua orang 1,2 kali lebih tinggi dibanding perempuan yang tinggal pada rumah tangga dengan anggota rumah tangga nonproduktif yang lebih kecil dari dua orang. Hasil ini sesuai dengan penelitian sebelumnya yang dilakukan oleh Majumder (2012) bahwa jumlah anggota rumah tangga usia nonproduktif yang merupakan beban ketergantungan yang harus ditanggung anggota rumah tangga produktif berpengaruh positif dan signifikan terhadap status bekerja perempuan. Hal ini berarti semakin banyak jumlah anggota rumah tangga usia nonproduktif membuat beban rumah tangga akan semakin tinggi. Perempuan cenderung masuk ke pasar kerja untuk membantu meringankan beban rumah tangga dan membantu mendapatkan penghasilan. Perempuan dianggap sebagai pencari nafkah sekunder dalam ekonomi rumah tangga (Spierings dkk., 2010; Ehsan, 2015).

\section{Status tempat tinggal}

Kesempatan kerja yang terdapat di sekitar wilayah dapat menjadi penentu perempuan untuk bekerja. Status tempat tinggal di wilayah perdesaan berpengaruh negatif dan signifikan terhadap status bekerja. Hal ini menunjukkan bahwa kesempatan kerja bagi perempuan banyak terbuka di wilayah perkotaan dibanding perdesaan. Oleh karena itu, perempuan yang tinggal di wilayah perkotaan lebih mudah untuk mendapatkan pekerjaan. Peluang perempuan perdesaan untuk bekerja lebih rendah 0,85 kali dibanding perempuan yang tinggal di wilayah perkotaan. Hasil ini tidak sejalan dengan penelitian sebelumnya di India (Majumder, 2012) yang menyatakan bahwa perempuan yang tinggal di perdesaan memiliki peluang yang lebih tinggi dibanding yang tinggal di wilayah perkotaaan. Wilayah perdesaan menyediakan peluang bekerja yang lebih tinggi pada perempuan dibanding wilayah perkotaan. Penelitian sejenis di Sulawesi Tengah (Kusumaningrum, 2013) mendapatkan bahwa pekerja perempuan lebih banyak yang tinggal di perdesaan daripada di perkotaan. Perbedaan hasil antara penelitian ini dengan penelitian sebelumnya salah satunya mungkin disebabkan karena kondisi wilayah dan struktur masyarakat yang berbeda. Sebagian besar perempuan usia produktif di Jawa Barat tinggal di wilayah perkotaan, yaitu mencapai $64 \%$. Selain itu struktur ekonomi di Jawa Barat ditopang oleh sektor industri yang sebagian besar berada di wilayah perkotaan Sektor pertanian yang biasanya menyerap tenaga kerja terbesar di wilayah perdesaan, ternyata di Jawa Barat hanya berkontribusi paling besar sebesar $30 \%$ saja. Hal inilah yang menjadi alasan mengapa peluang perempuan di wilayah perkotaan menjadi lebih tinggi. Hasil penelitian ini sesuai dengan penelitian sebelumnya yang dilakukan oleh Rangkuti (2009) yang menyatakan bahwa mereka yang tinggal di perkotaan mempunyai partisipasi bekerja yang lebih tinggi daripada mereka yang tinggal di perdesaan. 


\section{PDRB per kapita}

Variabel kabupaten kota yang digunakan dalam penelitian ini salah satunya adalah rata-rata pertumbuhan PDRB kabupaten/kota. Pertumbuhan PDRB per kapita berpengaruh positif dan signifikan terhadap status bekerja perempuan. Setiap kenaikan $1 \%$ pertumbuhan rata-rata PDRB per kapita maka peluang bekerja perempuan akan naik sebesar 1,11 kali lebih tinggi. Kecenderungan untuk bekerja bagi kaum perempuan akan lebih tinggi bagi mereka yang tinggal di kabupaten/ kota dengan tingkat PDRB per kapita yang lebih tinggi.

Hasil penelitian ini sesuai dengan penelitian yang dilakukan oleh Cipollone \& D'Ippoliti (2011) yang dilakukan di Italia bahwa PDB berpengaruh signifikan dan positif terhadap status bekerja perempuan. Semakin tinggi nilai PDRB perkapita, semakin tinggi pula peluang perempuan untuk bekerja. Kondisi ekonomi yang baik membuat kesempatan kerja terbuka sehingga perempuan cenderung masuk ke pasar kerja.

\section{Kontribusi sektor pertanian terhadap PDRB}

Sektor pertanian adalah sektor yang memiliki kesempatan luas dalam menyerap tenaga kerja, terutama pada sektor pertanian informal. Fleksibilitas sektor pertanian ini memberikan peluang bagi perempuan, terutama yang tidak dapat bersaing di pasar kerja, memilih bekerja di sektor pertanian terutama pertanian informal. Kontribusi sektor pertanian terhadap PDRB positif dan signifikan berpengaruh terhadap status bekerja perempuan. Peluang bekerja perempuan akan semakin tinggi pada perempuan yang tinggal pada kabupaten/ kota yang memiliki capaian distribusi sektor pertanian yang 1,02 kali lebih tinggi dibanding kabupaten/kota yang capaian kontribusi sektor pertaniannya lebih rendah $1 \%$.

\section{Rata-rata lama sekolah}

Rata-rata lama sekolah merupakan salah satu indikator pendidikan pada level makro yang dalam hal ini adalah kabupaten/kota. Rata-rata lama sekolah berpengaruh positif dan signifikan terhadap status bekerja perempuan. Setiap kenaikan satu tahun rata-rata lama sekolah suatu kabupaten/kota maka peluang bekerja perempuan di daerah tersebut naik sebesar sebesar 1,14 kali lebih tinggi dibanding wilayah lain yang lebih rendah. Hasil penelitian ini sejalan dengan penelitian sebelumnya oleh Mehrotra dan Parida (2017) bahwa rata-rata lama sekolah berpengaruh positif dan signifikan terhadap keputusan bekerja perempuan. Hasil ini mengindikasikan bahwa setelah perempuan menempuh jenjang pendidikan tertentu maka mereka mulai mencari pekerjaan.

\section{Efek random pada status bekerja perempuan}

Perbedaan status bekerja perempuan disebabkan oleh adanya variasi pada level individu (78,49\%), rumah tangga (20,39\%), dan kabupaten/kota $(1,12 \%)$. Hal ini berarti status bekerja perempuan paling besar ditentukan oleh individu. Individu berperan paling besar dalam menentukan dirinya apakah akan bekerja atau tidak. Hasil ini sejalan dengan penelitian sebelumnya (Spierings dkk., 2010) yang menyatakan bahwa faktor individu adalah penentu status bekerja perempuan. Individu pada akhirnya yang memiliki kewenangan untuk memutuskan terhadap pilihannya untuk bekerja atau tidak. Kondisi ini sejalan dengan teori alokasi waktu (Becker, 1992) yang lebih menitikberatkan pada peran individu dalam menentukan keputusan perempuan untuk menghabiskan waktunya untuk bekerja atau tidak. Konsekuensinya jika individu memilih salah satu pilihan berarti waktu untuk pilihan yang lain akan semakin berkurang.

\section{KESIMPULAN}

Hasil penelitian ini menunjukkan bahwa pendidikan merupakan faktor utama dalam menentukan perempuan untuk bekerja. Pendidikan dapat meningkatkan kemampuan dan pengetahuan perempuan. Oleh karenanya, capaian pendidikan meningkatkan kualitas tenaga kerja perempuan. Pemerintah dapat mempermudah dan meningkatkan akses pendidikan terutama bagi perempuan. Pemerintah perlu memperbesar investasi di bidang pendidikan sehingga sarana dan prasarana pendidikan dapat dijangkau oleh semua lapisan masyarakat termasuk perempuan. 
Selanjutnya, tempat tinggal di perkotaan memperbesar peluang kerja perempuan. Artinya kesempatan kerja di perkotaan lebih besar dan terbuka dibanding di perdesaan. Kebijakan yang dapat ditempuh yaitu dengan membuka kesempatan kerja di daerah perdesaan dan mengaktifkan kembali program-program pemerintah dalam rangka meningkatkan peran perempuan dalam pasar kerja. Pemberdayaan perempuan dilakukan melalui kegiatan-kegiatan dasawisma, PKK, dan pelatihan ketrampilan sehingga perempuan di desa semakin berdaya dan mandiri.

Lebih jauh lagi, keberadaan anggota rumah tangga usia nonproduktif dapat menghambat perempuan untuk bekerja. Hal ini karena keberadaannya membutuhkan pengasuhan dan perawatan perempuan sebagai penanggung jawab rumah tangga. Oleh karenanya, dibutuhkan tempat penitipan balita yang murah dan terjangkau oleh rumah tangga yang tidak dapat membayar baby sitter.

\section{DAFTAR PUSTAKA}

Asiati, D. (2002). Penawaran tenaga kerja perempuan kawin di Indonesia (Analisis data Susenas 2002) [Tesis Master, Universitas Indonesia]. https:// library.ui.ac.id/detail?id=96425\&lokasi=lokal

BPS/Badan Pusat Statistik. (2017). Konsep dan definisi survei sosial ekonomi nasional (Susenas Maret 2018). Badan Pusat Statistik.

BPS/Badan Pusat Statistik. (2018). Indikator pasar tenaga kerja Indonesia Agustus 2018. Badan Pusat Statistik.

Becker, G. S. (1992). Human capital and the economy. Proceedings of the American Philosophical Society, 136(1), 85-92. https://www.jstor.org/ stable/986801

Cipollone, A., \& D'Ippoliti, C. (2011). Women's employment: Joining explanations based on individual characteristics and on contextual factors. The American Journal of Economics and Sociology, 70(3), 756-783. https://www. jstor.org/stable/41329208

Cipollone, A., Vallanti, G., \& Patacchini, E. (2012). Women's labour market performance in Europe: Trends and shaping factors. https://www.ceps.eu/download/ publication $/$ ? $\mathrm{id}=7700 \& \mathrm{pdf}=$ Women $\% 20$ Labour\%20Market $\% 20$ Performance $\% 20$ in $\% 20$ Europe.pdf
Cools, S., Markussen, S., \& Strøm, M. (2017). Children and careers: How family size affects parents' labor market outcomes in the long run. Demography, 54(5), 1773-1793.

Ehrenberg, R. G., \& Smith, R. S. (2012). Modern labor economics theory and public policy (11th ed.). Prentice Hall.

Ehsan, S. (2015). Female labor force participation, its determinants and effect on GDP in Pakistan [Tesis Master, Eastern Mediterranean University]. http://i-rep.emu.edu.tr:8080/jspui/ bitstream/11129/2906/1/ehsansaad.pdf

Gaddis, I., \& Klasen, S. (2014). Economic development, structural change, and women's labor force participation: A reexamination of the feminization $U$ hypothesis. Population and Economics, 27, 639-681. https://doi. org/10.1007/s00148-013-0488-2

Ghozali, I. (2016). Analisis multilevel untuk bidang ekonomi, bisnis, kesehatan, psikologi, dan pendidikan dengan program IBM SPSS 23. Yoga Pratama.

Goldin, C. (1995). The U-shaped female labor force function in economic development and economic history. Dalam T. P. Schultz, Investment in women's human capital and economic development (61-90). University of Chicago Press. https://scholar.harvard.edu/files/goldin/ files/the_u-shaped_female_labor_force_function_in_economic_development_and_economic_history.pdf

Groesbeck, J. D., \& Israelsen, L. D. (1994). The relationship between household size, real wages, and labor force participation rates of men and women. Economic Research Institute Study Papers, 94(13), 1-17. https://digitalcommons. usu.edu/eri/43

Hosney, S. H. (2016). Factors influencing female labor force participation in Egypt and Germany: A comparative study. SOEPpapers on Multidisciplinary Panel Data Research, 826. https://www.econstor.eu/ bitstream/10419/130586/1/856920835.pdf

Hox, J. J. (2010). Multilevel analysis: Techniques and applications (2nd ed.). Routledge.

ILO/International Labour Organization. (2017). Laporan ketenagakerjaan Indonesia 2017. https://www.ilo.org/wcmsp5/groups/public/--asia/---ro-bangkok/---ilo-jakarta/documents/ publication/wcms_613626.pdf

Kementerian Pemberdayaan Perempuan dan Perlindungan Anak. (2016). Statistik gender tematik: Potret ketimpangan gender dalam ekonomi. https:/www.kemenpppa.go.id/lib/ uploads/list/53185-statistik-gender-tematik2016-ketimpangan-ekonomi.pdf 
Kusumaningrum, I. (2013). Pola dan determinan penawaran tenaga kerja perempuan di Provinsi Sulawesi Tengah tahun 2011 (Analisis data Susenas 2011) [Tesis Master, Universitas Gadjah Mada]. http://etd.repository.ugm.ac.id/ home/detail_pencarian/59515

Majumder, R. (2012). Female labor supply in India: Proximate determinants. MPRA Paper, 43250. https://mpra.ub.uni-muenchen.de/43250/1/ MPRA_paper_43250.pdf

Mehrotra, S., \& Parida, J. K. (2017). Why is the labour force participation of women declining in India? World Development, 98, 360-380. https://doi.org/10.1016/j.worlddev.2017.05.003

Nikulin, D. (2017). The impact of ICTs on women's economic empowerment. Dalam H. Kaur, E. Lechman, \& A. Marszk. Catalyzing development through ICT adoption: The developing world experience (hal. 15-24). Springer, Cham. https://doi.org/10.1007/978-3-319-56523-1

Octaviana, F. A. (2017). Pemodelan status bekerja ibu rumah tangga menggunakan model multilevel dengan respon biner [Tesis Master, Institut Teknologi Surabaya]. https://repository.its. ac.id/2093/

Schaner, S., \& Das, S. (2016). Female labor force participation in Asia: Indonesia country study. https://www.adb.org/publications/female-laborforce-participation-asia-indonesia-study

Schultz, T. W. (1961). Investment in human capital. The American Economic Review, 51(1), 1-17. https://www.jstor.org/stable/1818907

UNDP/ United Nations Development Programme. (2016). Goal 5: Gender equality. https:// www.undp.org/sustainable-developmentgoals\#gender-equality

Setyawati, A. W. (2010). Modal sosial dan pengaruhnya terhadap penawaran tenaga kerja di Indonesia [Tesis Master, Universitas Indonesia]. http://lib.ui.ac.id/abstrakpdf.jspdetail?id= 20341180\&lokasi=lokal
Shi, Y. (2015). What drive females' labor force participation in China? A study comparing urban and rural area [Tesis Master, Georgetown University]. https://repository.library.georgetown. edu/bitstream/handle/10822/1040867/Shi_ georgetown_0076M_13386.pdf?sequence=1

Spierings, N., Smits, J., \& Verloo, M. (2010). Microand macrolevel determinants of women's employment in six Arab countries. Journal of Marriage and Family, 72, 1391-1407. https:// www.jstor.org/stable/40865617

Suhaida, M. A., Nurulhuda, M. S., \& Yap, S. (2013). Access to ICT as moderating factor to women's participation in the labor force: a conceptual framework. International Journal of Trade, Economics and Finance, 4(4), 197-201. https:// doi.org/10.7763/IJTEF.2013.V4.285

Rangkuti, H. (2009). The role of migration on poverty reduction in Indonesia: A quest on the migrants' welfare before and after migration. https://iussp.org/sites/default/files/ event_call_for_papers/paper $\% 20$ Hasnani $\% 20$ Rangkuti\%20-\%20IUSSP\%20Busan.pdf

Tanaka, S., \& Muzones, M. (2016). Female labor force participation in Asia: Key trends, constraints, and opportunities. https://www.adb.org/publications/female-labor-force-participation-asia

Verick, S. (2014). Female labor force participation in developing countries. https://wol.iza.org/ articles/female-labor-force-participation-indeveloping-countries/long

Widarti, D. (1998). Determinants of labour force participation by married women: The case of Jakarta. Bulletin of Indonesian Economic Studies, 34(2), 93-120. https://doi.org/10.108 $0 / 00074919812331337350$ 